Cahit Yavuz, (1) Nurten Yavuz*

\title{
Excessive Punctate Palmoplantar Keratoderma Type 1 Lesions in a Patient Accompanied with Renal Failure
}

\author{
Böbrek Yetmezliğinin Eşlik Ettiği Hastada Görülen \\ Aşııı Punktat Palmoplantar Keratoderma \\ Tip 1 Lezyonları
}

\section{Öz}

Palmoplantar keratodermalar (PPK) el ve ayaklarda kalınlaşma ile karakterli bir grup hastalıktır. Kalıtımsal veya edinsel olabilirler. Difüz, fokal ve punktat formlar ana gruplarıdır. PPK'lerde esas problem stratum korneumun anormal proliferasyonudur. Polikliniğimize başvuran hiperkeratotik nodüler tarzda el içi ve ayak tabanı lezyonları olan hasta yazıda ele alınmıştır.

Anahtar kelimeler: Palmoplantar keratoderma, Buschke-Fischer-Braver hastalığı, böbrek yetmezliği

\section{Abstract}

Palmoplantar keratodermas (PPKs) are a group disease characterized by thickening of palms of the hands and soles of the feet. They may be inherited or acquired. Diffuse, focal and punctate forms are the main groups. Abnormal proliferation of stratum corneum is the main problem in PPKs. In this study, the patient who admitted to our outpatient clinic with hyperkeratotic nodular lesions in the palm of the hand and the sole of the foot was discussed.

Keywords: Palmoplantar keratoderma, Buschke-Fischer-Braver disease, renal failure

Sağlık Bilimleri Üniversitesi, Konya Eğitim ve Araştırma Hastanesi, Dermatoloji Kliniği, Konya, Türkiye

*Sağlık Bilimleri Üniversitesi, Konya Eğitim ve Araştırma Hastanesi, Plastik Rekonstrüktif ve Estetik Cerrahi, Kliniği Konya, Türkiye

Yazışma Adresi/

Correspondence:

Cahit Yavuz, Sağlık Bilimleri Üniversitesi, Konya Eğitim ve Araştırma Hastanesi, Dermatoloji Kliniği, Konya, Türkiye E-posta: cahit.yavuz@saglik.gov.tr ORCID-ID:

orcid.org/0000-0003-4675-8127 Geliş Tarihi/Submitted: 28.10.2016 Kabul Tarihi/Accepted: 3.11.2016

๑Telif Hakkı 2019 Türk Dermatoloji Derneği

Türk Dermatoloji Dergisi, Galenos Yayınevi tarafından basılmışır.

\section{Giriş}

Palmoplantar keratodermalar (PPK) el ve ayaklarda kalınlaşma ile karakterli bir grup hastalıktır. Kalıtımsal veya edinsel olabilirler. Difüz, fokal ve punktat formlar ana gruplarıdır. PPK'lerde esas problem stratum korneumun anormal proliferasyonudur.

Punktat PPK tip 1 ilk olarak 1879 yılında bildirildi (1). 1910 yılında Buschke ve Fischer hastalığı tanımladı (2). Brauer 1913 yılında hastalığın kalıtımsal yönünü tanımladı ve o günden sonra hastalık "Buschke-FischerBrauer hastalığı" olarak anılmaya başlandı (3). Hastalık genellikle yaşamın erken dönemlerinde başlamaktadır. Ancak geç başlangıçlı Buschke-Fischer-Brauer tipi tanımlanmıştır (4). Hastalığın prevelansının $1,17 / 100000$ olduğu sanılmaktadır (2). Patofizyolojisi net olarak bilinmemektedir.
Moleküler genetik çalışmalarda sorumlu genin 15q22 lokasyonunda yerleştiği gösterilmiştir (5).

El içi ve ayak tabanında yerleşen çok sayıda hiperkeratotik küçük papüller hastalığın klinik bulsudur. Lezyonlar ayak tabanında basınç etkisiyle daha belirgin olma eğilimindedirler. Bununla birlikte hastalar el içi lezyonları günlük aktiviteler arasında koparmaktadırlar. Bu nedenle ayak taban lezyonlarının daha belirgin olduğu düşünülmektedir (6).

Buschke-Fischer-Brauer keratoderması benign ve malign durumlarla birliktelik gösterebilir. Kolon karsinomu, prostat kanseri, meme kanseri ve küçük hücreli dışı akciğer kanseri birlikte görülebilecek malign hastalıklardandır. Nörolojik bozukluklar, tırnak distrofileri, 
psoriasis ve keratozis pilaris ise birlikte olabilecek benign durumlardandır (7).

\section{Olgu Sunumu}

Altmış üç yaşında erkek hasta yakınları tarafından el içi ve ayak tabanındaki çok sayıda ağrılı lezyonlarla polikliniğimize getirildi (Resim 1,2). Hastanın anamnezinden bu lezyonların çocukluk çağından bu yana olduğu ve böbrek yetmezliği tanısıyla haftada 3 kez diyalize girdiği öğrenildi. Böbrek yetmezliği tanısı alıp günlük aktiviteleri kısıtlandıktan sonra lezyonların arttığını belirtti. Hastanın babasında ve bir oğlunda da aynı lezyonlar varmış. Başlarda kendisi el içi ayak lezyonları temizleyebilirken yaşı ilerledikçe böbrek hastalığının da etkisiyle temizlemekte zorlandığı öğrenildi. Başlangıçtan bu yana kendisi lezyonları temizleyebildiği için tedavi almamış.

Dermatolojik muayenede el içi ve ayak tabanında, ayak tabanında daha belirgin olmak üzere çok sayıda küçük çaplı hiperkeratotik papüllerin olduğu görüldü. Ayak taban lezyonları nedeniyle hastanın ayakta durmakta zorluk çektiği öğrenildi. Ayak taban lezyonlarının son zamanlarda artışı böbrek yetmezliği nedeniyle hastanın lezyonları temizleyememesine bağlandı.

\section{Tartışma}

Buschke-Fischer-Brauer keratodermasında esas sorun stratum korneumun aşırı proliferasyonudur. Lezyonlar el içi ve ayak tabanında yerleşim gösterir. Hastalık yaşamın erken

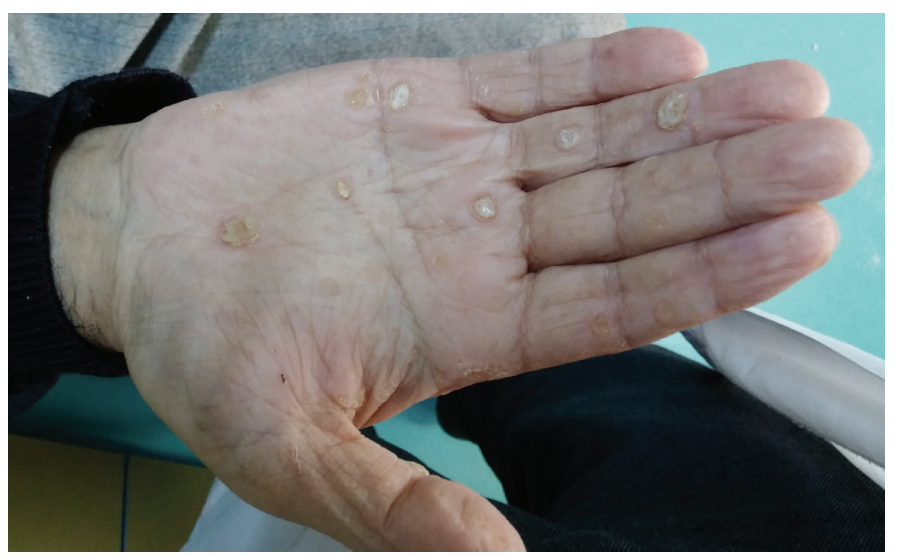

Resim 1. Ağrılı hiperkeratotik el içi lezyonları

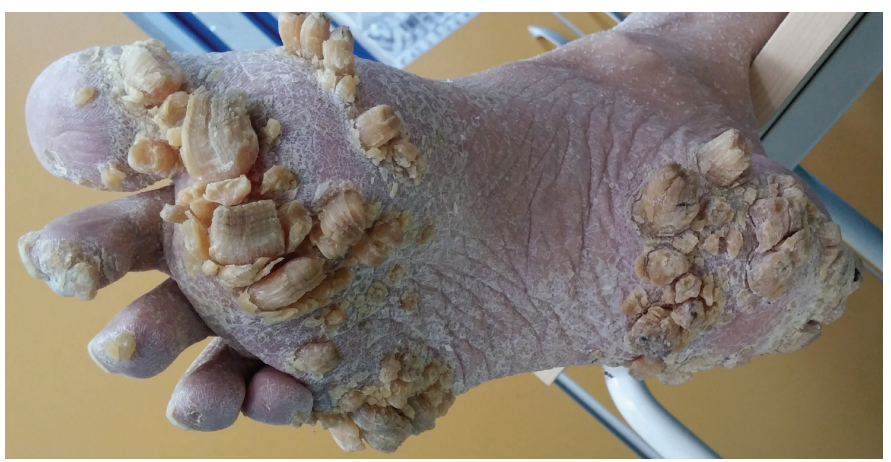

Resim 2. Ağrılı hiperkeratotik ayak tabanı lezyonları dönemlerinde genellikle çocuklukta başlar. Geç başlangıçlı tipi tanımlanmışır. Patofizyolojisi net olarak bilinmemekle birlikte sorumlu genin $15 q 22$ lokusunda bulunduğu Gao ve ve ark., (5) tarafından bildirilmiştir.

Buschke-Fischer-Brauer keratoderması klinik olarak el ve ayaklarda yerleşen düzensiz sınırlı hiperkeratotik papüllerle karakterlidir. Lezyonlar çoğunlukla asemptomatik olmakla birlikte ayak taban lezyonları basınç etkisiyle ağrılı olabilir. Nesneleri elle tutmak ve yürümek hasta için ağrı verici olabilir. Tırnaklarda kalınlaşma, subungual hiperkeratozis ve renk değişiklikleri eşlik edebilir.

Arsenik maruziyeti, verruka vulgaris, costanın akrokeratoelastoyidozu, kallus ve fokal akral hiperkeratoz ayırıcı tanılar arasında düşünülmelidir. Hastamızın lezyonundan alınan biyopsinin histopatolojik incelemesinde boynuzsu tabakada kalınlaşma ve alt yapılarda düzleşme görüldü.

Birlikte olabilecek benign ve malign durumlar açısında hasta değerlendirildi. Eşlik eden böbrek yetmezliği dışında özellik saptanmadı.

Buschke-Fischer-Brauer keratodermasında tedavi zordur. Küratif olmamakla birlikte daha çok keratolitik ajanlar tercih edilmektedir. Sistemik retinoidler yan etkileri nedeniyle yakın izlemle hastalara verilebilir. Alitretinoin hastalar için bir alternatif tedavi seçeneği olabilir. Raone ve ark., (8) bir hastanın alitretinoin tedavisinden fayda gördüğünü bildirmişlerdir. Cerrahi eksizyon uygun olgularda düşünülmelidir.

Hastamızın yürümesini engelleyen ayak tabanı lezyonları için cerrahi eksizyon planladık ve uygulandı. Hastaya eksizyon sonrası böbrek yetmezliği nedeniyle sistemik retinoid başlanamadı. Topikal keratolitik ajanlarla tedaviye devam edildi. Hasta cerrahi eksizyon sonrası ayakta durmaya ve günlük işlerini az da olsa kendisi yapabilmeye başladı.

\section{Etik}

Hasta Onayı: Hastanın onayı alınmıştır.

Hakem Değerlendirmesi: Editörler kurulu tarafından değerlendirilmiştir.

\section{Yazarlık Katkıları}

Konsept: C.Y., Dizayn: C.Y., Veri Toplama veya İşleme: C.Y., Analiz veya Yorumlama: C.Y., Literatür Arama: C.Y., Tedavi ve Takip: N.Y., Yazan: C.Y.

Çıkar Çatışması: Yazarlar tarafından çıkar çatışması bildirilmemiştir.

Finansal Destek: Yazarlar tarafından finansal destek almadıkları bildirilmiş̧ir.

\section{Kaynaklar}

1. El Amri I, Mamai O, Ghariani N, et al. Etude clinique et genetique de la keratodermie palmoplantaire de Buschke-Fischer-Brauer dans une famille tunisienne. Ann Dermatol Venereol 2010;137:269-75.

2. Oztas $\mathrm{P}$, Alli N, Polat M, et al. Punctate palmoplantar keratoderma (BrauerBuschke-Fischer Syndrome). Am J Clin Dermatol 2007;8:113-6. 
3. Gupta R, Mehta S, Pandhi D, et al. Hereditary punctate palmoplantar keratoderma (PPK) [Brauer-Buschke-Fischer Syndrome]. J Dermatol 2004;31:398-402.

4. Al Mutairi N, Joshi A, Nour-Eldin O. Punctate palmoplantar keratoderma (Buschke-Fischer-Brauer Disease) with psoriasis: A rare association showing excellent response to acitretin. J Drugs Dermatol 2005;4:627-34.

5. Gao M, Yang S, Li M, et al. Refined localization of a punctate palmoplantar keratoderma gene to a 5.06-cM region at $15 q 22.2-15 q 22.31 . \mathrm{Br} J$ Dermatol 2005;152:874-8.
6. Antonio JR, Oliveira GB, Rossi NC, et al. Exuberant clinical picture of Buschke-Fischer-Brauer palmoplantar keratoderma in bedridden patient. An Bras Dermatol 2014;89:819-21.

7. Kumari R, Thappa D. Keratosis palmoplantaris punctata (BuschkeFischer-Brauer) with keratosis pilaris. Indian J Dermatol 2006;51:2234.

8. Raone B, Raboni R, Patirizi A. Alitretinoin: a new tretamnet option for heraditary punctate palmoplantar keratoderma (Brauer- BuschkeFischer syndrome). J Am Acad Dermatol 2014;71:e48-9. 